Société d'histoire de la révolution de 1848 et des révolutions du XIXe siècle

$22 \mid 2001$

Autour de Décembre 1851

\title{
Le Deux décembre ou le sacre de l'Auteur : les usages politiques d'un lieu commun de l'écriture de l'histoire
}

Olivier Le Trocquer

\section{OpenEdition}

Journals

Édition électronique

URL : http://journals.openedition.org/rh19/249

DOI : $10.4000 /$ rh19.249

ISSN : $1777-5329$

\section{Éditeur}

La Société de 1848

Édition imprimée

Date de publication : 1 juin 2001

Pagination : $97-119$

ISSN : 1265-1354

\section{Référence électronique}

Olivier Le Trocquer, «Le Deux décembre ou le sacre de l'Auteur : les usages politiques d'un lieu

commun de l'écriture de l'histoire », Revue d'histoire du XIXe siècle [En ligne], 22 | 2001, mis en ligne le

30 novembre 2016, consulté le 20 avril 2019. URL : http://journals.openedition.org/rh19/249 ; DOI :

$10.4000 /$ rh19.249

Ce document a été généré automatiquement le 20 avril 2019

Tous droits réservés 


\title{
Le Deux décembre ou le sacre de l'Auteur: usages politiques d'un lieu commun de l'écriture de l'histoire
}

\author{
Olivier Le Trocquer
}

\section{ABSTRACTS}

$2^{\text {nd }}$ December, or the consecration of the Author: the political use of a commonplaceThis paper extends to the field of political and institutional history the notion of author-function set up by Michel Foucault; the method followed here examines what Louis-Napoléon Bonaparte did to undertake his coup. A long-term authorship strategy can be seen: the publication of his Works, gathered after the February 1848 revolution, was conceived and reshaped depending on each shift in political perspective. The figure of a Author in history, the law and the nation, was gradually set up. Taken from models already experienced in Boulogne, the initial official texts on the coup (decrees and proclamations) are discursive delusions, which aim to conceal the criminal dimension of the coup in regard to the law, and to found the authority of Louis-Napoléon Bonaparte with the help of a mythical past.

En étendant la notion de fonction-auteur, élaborée par Michel Foucault, au champ de l'histoire politique et institutionnelle, la démarche suivie examine ce dont s'autorise Louis-Napoléon Bonaparte pour commettre son coup d'État. Une stratégie autoriale apparaît sur la longue durée : l'édition de ses CEuvres, rassemblées après la révolution de Février, est conçue et remaniée en fonction de chaque renouvellement de perspective politique. La figure d'un Auteur de l'histoire, de la loi et de la nation est ainsi progressivement constituée. Repris de modèles déjà expérimentés à Boulogne, s'autorisant d'une telle figure, les actes initiaux du coup d'État 
- décrets et proclamations - constituent des leurres discursifs qui visent à en escamoter la dimension criminelle au regard du code pénal et à fonder l'autorité de Louis-Napoléon Bonaparte dans une antériorité mythique.

INDEX

Mots-clés: Histoire culturelle, Histoire politique, Littérature, Représentations 